\title{
INVESTIGATION OF CHANGES IN CLIMATE DATA USING CHECKERBOARD: THE CASE OF AKARÇAY BASIN
}

\author{
SAPLIOGLU, K. $.^{*}-$ KILIT, M. ${ }^{2}-$ ŞENEL, F. A. ${ }^{3}$ \\ ${ }^{1}$ Department of Civil Engineering, Faculty of Engineering, Süleyman Demirel University \\ Isparta, Turkey \\ (phone: +90-246-211-1213) \\ ${ }^{2}$ Department of Civil Engineering, Faculty of Engineering, Afyon Kocatepe University \\ Afyon, Turkey \\ ${ }^{3}$ Department of Computer Engineering, Faculty of Engineering, Süleyman Demirel University \\ Isparta, Turkey \\ *Corresponding author \\ e-mail: kemalsaplioglu@sdu.edu.tr \\ (Received 24 $4^{\text {th }}$ Oct 2018; accepted 20 $0^{\text {th }}$ Dec 2018)
}

\begin{abstract}
Water resources planning requires very good data set and accurate analyses, one of which is a trend identification procedure. Different trend analyses are available in the literature and one of the most commonly used one is the Mann-Kendall trend analysis. The biggest problem of this analysis is that trends change with the selection of different time periods. Although many researchers have tried to find different solutions to this problem, in this study, trends are set for all combinations of the available data to cover at least 10-year periods and the results are displayed on a 3-dimensional checkerboard. For the application precipitation and temperature data are considered from 5 meteorology stations in the Akarçay, Turkey.
\end{abstract}

Keywords: Afyon, period, trend, rainfall, temperature

\section{Introduction}

Rapid population growth and industrialization have a huge impact on global climate. Particularly in recent decades, the concept of climate change has received growing attention among the researchers. Studies especially address the amount of precipitation (Paul et al., 2017), precipitation intensity (Olive et al., 2017), mean temperature (Khan et al., 2017), extreme temperature conditions (Zhao et al., 2017), amount of evaporation (Xu et al., 2007), stream flow (Saplioglu et al., 20014) and groundwater level fluctuations (Gebert et al., 2007). These are also mathematical (Sing et al., 2016), statistical (Zeleňáková, 2017; Kristo et al., 2017; Onyutha, 2016) and graphical (Cui et al., 2017; Sen, 2012) description studies about trend analysis.

Statistical models are crucial for trend detections. Many researchers conducted statistical studies on trends and proposed different methods (Saplioglu, 2015). One of the most widely used methods is the Mann-Kendall test, which has been employed to analyze seasonal and annual precipitation trends in Bangladesh (Baria et al., 2016), precipitation and drought trends of the Aegean region, Turkey (Bacanli, 2016), precipitation trends in Sicily (Cannarozzo et al., 2006), around the Nile River (Onyutha et al., 2016), in Turkey (Partal and Kahya, 2006), Florya, Istanbul (Guclu et al., 2018), Córdoba, Argentina (Casaa and Nasello, 2010), in the Iberian peninsula (Bustins, 2008), in three different regions of Japan (Yue and Hashino, 2003), in Brazil (Carvalhao et al., 2014), in Sudan (Goanstera et al., 2015), precipitation and temperature trends in the 
Northeastern United States (Karmesha, 2012), stream trends and the impact of precipitation and subsurface waters on these trends in India (Kumar et al., 2009), changes in hourly precipitation in Peninsular Malaysia (Syafrina et al., 2018), temporal and spatial precipitation changes and estimation in Mongolia (Kim et al., 2011) and 6minute precipitation intensity trends in Australia's southern regions (Kamruzamana et al., 2016).

Some researchers have applied the Mann-Kendall test for different time periods and observed that the results were different. For example, Baria et al. (2016), analyzed 50year data in northern Bangladesh and observed no trends except for one station. They also found different downward trends in all stations for 1990 and beyond. Cannarozzo (2006) conducted a study on 247 stations leading to different trends for three different periods as 1921-2000 (170 trends), 1931-1960 (65 trends) and 1961-1990 51 trends. Although Carvalhao et al. (2014) identified a significant trend from 1899 to 1970 they did not detect any trend from 1970 and beyond. Goanstera et al. (2015), investigated precipitation amount to identify trends from 1950 to 2009 and 1970 to 2009. They observed statistically significant trends during the former part of the records, but no statistically significant trends along the latter part. Seo et al. (2012), used the MannKendall test for different time periods and displayed the confidence intervals of the trends on a checkerboard. Studies suggest that using the Mann-Kendall test for different periods yields different results.

In this study of temperature and precipitation trends are analysed in which is one of Turkey's 25 sub-basins Akarçay. The Mann-Kendall test was used for trend analysis. However, the entire data set was scanned at least 10 years during this process. The results are presented as $3 \mathrm{D}$ graphics. The most important aim of the study is to show that the trends may change when the period of the selected period changes rather than determining the current trend.

\section{Materials and methods}

This study investigates possible precipitation and temperature trends in Akarçay basin, Turkey.

\section{Akarçay basin features}

Akarçay is one of the 25 basins in Turkey and it has a total drainage area of $7,337 \mathrm{~km}^{2}$ along the closed depression basin extending between Uşak-Banaz in the West and Konya-Doğanhisar in the East. It length is parallel to the tectonic line between the Taurus Belt and Afyon Metamorphics with orientation along 38.7380-39.0098 NW30.5604-31.4217 SE direction its length - $160 \mathrm{~km}$ with $70 \mathrm{~km}$ width (Fig. 1).

Tables 1 and 2 present statistical parameters of annual homogenized precipitation records and temperature records, respectively

\section{Methods}

It is emphasized in this study that the start and end years are crucial in the classical Mann-Kendall tests. In any analysis, trends vary according to start and end years. In the same time series record there may be more than one trend subsequently with different slopes. For this reason, data set is sub-divided into minimum 10-year periods and the 
Mann-Kendall test is performed on each period and the results are presented on 3D checkerboard graphics.

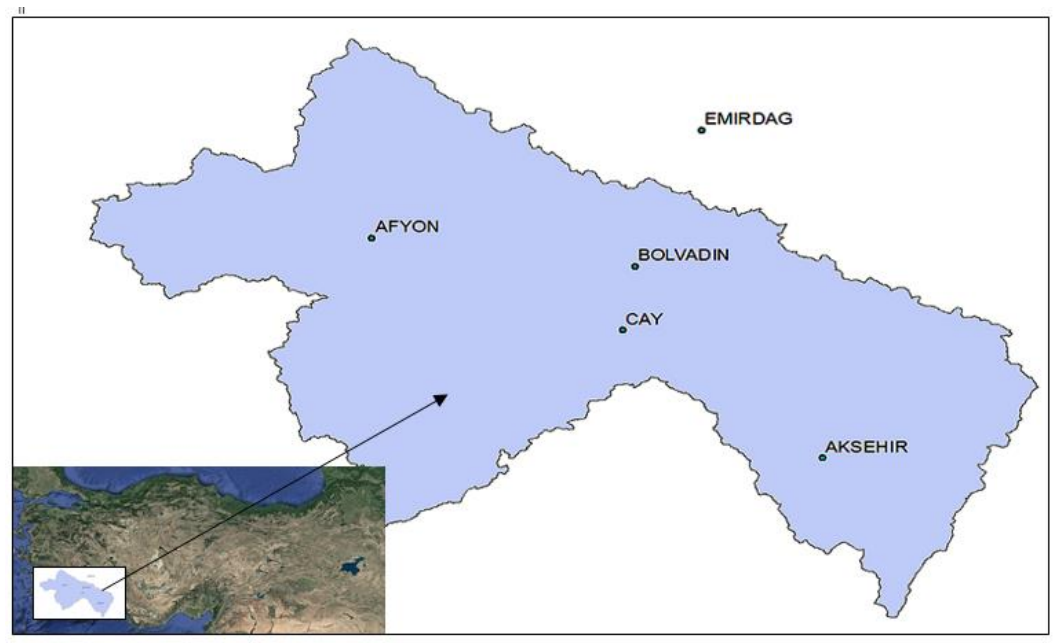

Figure 1. Site location map of Akarçay basin

Table 1. Statistical analysis of data from precipitation measurement stations of Akarçay basin

\begin{tabular}{c|c|c|c|c|c}
\hline & Afyon & Akşehir & Bolvadin & Çay & Emirdăg \\
\hline Altitute & 1034 & 1002 & 1018 & 996 & 983 \\
Latitude & $38.7380 \mathrm{~N}$ & $38.3688 \mathrm{~N}$ & $38.7268 \mathrm{~N}$ & $38.5903 \mathrm{~N}$ & $39.0098 \mathrm{~N}$ \\
Longitude & $30.5604 \mathrm{E}$ & $31.4297 \mathrm{E}$ & $21.0477 \mathrm{E}$ & $31.0315 \mathrm{E}$ & $31.1463 \mathrm{E}$ \\
Mean (mm) & 434.70 & 615.42 & 384.03 & 526.23 & 401.18 \\
Standard deviation & 91.98 & 130.20 & 60.29 & 98.84 & 99.34 \\
Kurtosis & 0.10 & 0.12 & -0.17 & -0.32 & 0.55 \\
Skewness & 0.22 & 0.39 & -0.31 & 0.30 & 0.17 \\
Maximum (mm) & 238.20 & 371.30 & 217.30 & 333.80 & 161.70 \\
Minimum (mm) & 679.10 & 942.70 & 484.20 & 751.30 & 698.70 \\
Initial data & 1929 & 1941 & 1957 & 1967 & 1953 \\
Number of data & 81 & 69 & 46 & 40 & 57 \\
Confidence level (95.0\%) & 20.34 & 31.28 & 17.90 & 31.61 & 26.36 \\
\hline
\end{tabular}

Table 2. Statistical analysis of data from temperature measurement stations of Akarçay basin

\begin{tabular}{|c|c|c|c|c|c|}
\hline & Afyon & Akşehir & Bolvadin & Çay & Emirdăg \\
\hline Mean $\left({ }^{\circ} \mathbf{C}\right)$ & 11.19 & 11.94 & 11.01 & 11.80 & 11.47 \\
\hline Standard deviation & 0.72 & 0.85 & 0.75 & 0.70 & 0.74 \\
\hline Kurtosis & -0.09 & 2.32 & 0.02 & 1.38 & -0.13 \\
\hline Skewness & -0.12 & -0.66 & 0.09 & -0.04 & 0.32 \\
\hline $\operatorname{Maximum}\left({ }^{\circ} \mathrm{C}\right)$ & 9.28 & 8.78 & 9.22 & 10.14 & 9.93 \\
\hline $\operatorname{Minimum}\left({ }^{\circ} \mathbf{C}\right)$ & 12.84 & 13.78 & 12.79 & 13.07 & 13.24 \\
\hline Initial data & 1929 & 1941 & 1969 & 1969 & 1965 \\
\hline Number of data & 81 & 64 & 41 & 41 & 45 \\
\hline Confidence level (95.0\%) & 0.16 & 0.21 & 0.24 & 0.36 & 0.22 \\
\hline
\end{tabular}




\section{Mann-Kendall test statistic}

The Mann-Kendall test (Mann, 1945; Kendall, 1970) is a nonparametric procedure, which does not make any assumption regarding the data distribution. The aim of the Mann-Kendall test is to verify whether a trend exists in a time series. If the hypothesis is rejected, it means that there is a trend. During any analysis, time series are divided into two groups; $\mathrm{x} 1, \mathrm{x} 2, \ldots$, $x n,(x i, x j)$. If $i<j$ for each $x i<x j$, then $P$ value is increased by one, in the opposite case, that is, for ... xi > xj, M value then the test statistics, $S=P-M$, is defined (Saplioglu et al., 2017).

Kendall correlation coefficient for $\mathrm{n}>10$ is calculated as follows (Eqs. 1-2).

$$
\begin{array}{r}
\mu_{s}=0 \text { ve } \sigma_{s}=\sqrt{n(n-1)(2 n+5) / 18} \\
\left.z=\begin{array}{ll}
\frac{s-1}{\sigma_{s}} & s>0 \\
0 & s=0 \\
\frac{s-1}{\sigma_{s}} & s<0
\end{array}\right]
\end{array}
$$

If the Z-score is less than $\alpha$ corresponding to $\mathrm{Z} / 2$ in a normal distribution, then the hypothesis is accepted, indicating that there is no trend. If the Z-score (Eq. 2) is greater than $\alpha$ corresponding to $\mathrm{Z} / 2$, then the hypothesis is rejected, suggesting that there is a trend. If $\mathrm{S}$ is positive, then it is an upward trend, on the other hand, if $\mathrm{S}$ is negative, then it is a downward trend. The Mann-Kendall test method is practical as it does not make any assumption regarding the data distribution (Saplioglu et al., 2014).

\section{Applied method}

The Mann-Kendall test statistic generally analyzes trends in series between a start and end points. This method iteratively arranges the start and end points and allows one to calculate trends in different periods (at least 10 years). These trend changes are displayed on a checkerboard. The $\mathrm{x}$ axis represents the start years, the $\mathrm{y}$ axis is for end years and the $\mathrm{z}$ axis stands for the confidence interval of the trend, and hence, this axis assumes values between -1 and 1 . The range from 0 to 1 indicates a downward trend while from -1 to 0 is for an upward trend. Generally at a confidence interval of $95 \%$, the results are considered as statistically significant indicating the presence of a trend. The blue color scale (-1-0) shows a downward trend while the red color (0-1) implies an upward trend. Software was generated using MATLAB in order to apply the method quickly and automatically (Fig. 2). This software was generated embedding the Mann-Kendall statistical subprogram (Fig. 3) into MATLAB.

\section{Results and discussion}

In the Akarçay basin, stations with data set suitable for the Mann-Kendall test (5 for precipitation and 5 for temperature) were selected and analyzed.

\section{Precipitation trends}

Mann-Kendall tests are performed in at least 10 different combinations on the precipitation data set for 5 stations. All results are summarized in tables and graphs. In the classic MannKendall tests, only one analysis is performed at the start and end times of a data set. 2628, 
1830, 990, 561 and 1176 Mann-Kendall tests are performed for Afyon, Akşehir, Bolvadin, Çay and Emirdağ, respectively (Table 3).

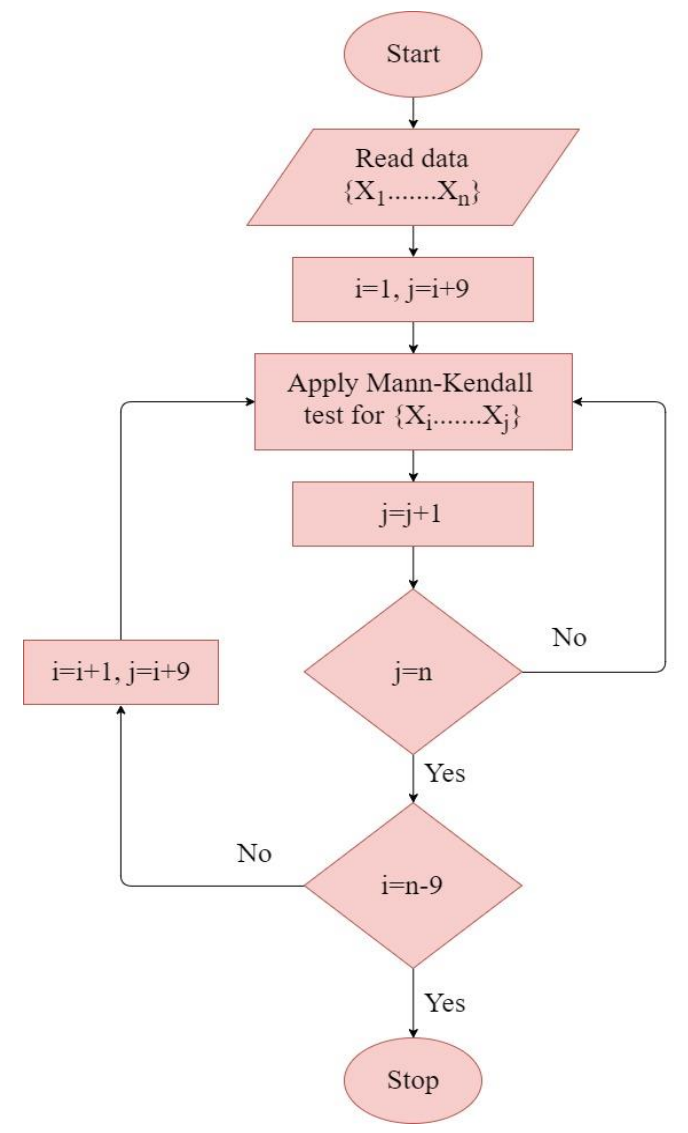

Figure 2. Flow diagram of the software for the model

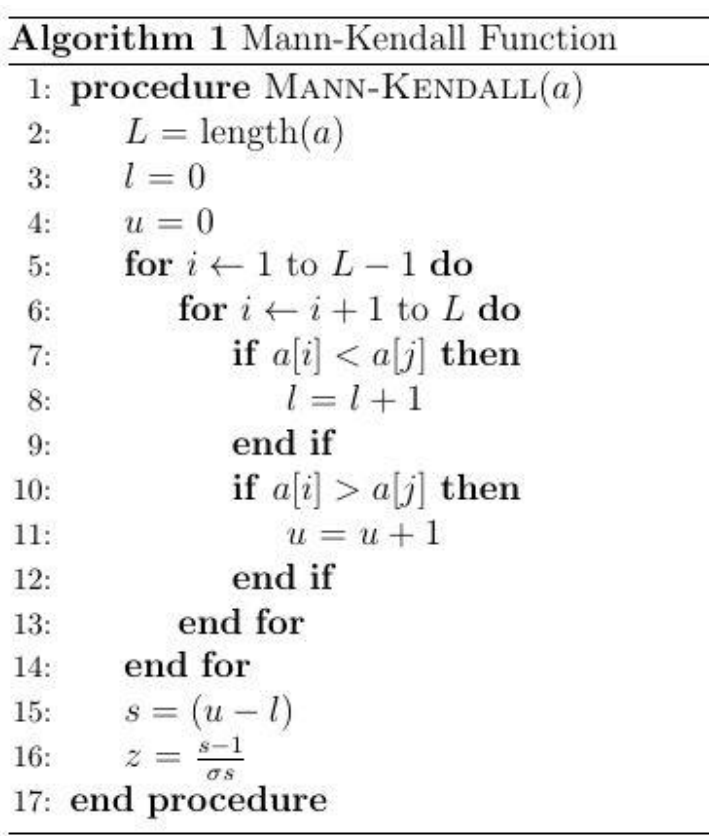

Figure 3. Algorithm of the Mann-Kendall test used in the software 
Table 3. Trend statistics for precipitation data

\begin{tabular}{c|c|c|c|c|c}
\hline & Iteration & Negative trend & Negative rate & Positive trend & Positive rate \\
\hline Afyon & 2628 & 524 & 19.94 & 112 & 4.26 \\
Akşehir & 1830 & 446 & 24.37 & 235 & 12.84 \\
Bolvadin & 990 & 3 & 0.30 & 2 & 0.20 \\
Cay & 561 & 42 & 7.49 & 1 & 0.18 \\
Emirdağ & 1176 & 46 & 3.91 & 64 & 5.44 \\
\hline
\end{tabular}

Trend analyses for different periods are visually presented on the checkerboard. Out of 2,628 Mann-Kendall tests applied to the Afyon precipitation data, 524 revealed a negative trend while 112 indicated a positive trend (Fig. 4). All data between the initial and final points indicate the presence of a negative trend. However, this can sometimes be misleading. For example, the analysis of Afyon station data over the period from 1929 to 2009 shows a trend at a confidence interval of $95 \%$, however, no trend is observed in the analysis of the data over the period from 1929 to 2008 or from 1930 to 2009. Similar examples can be found in the literature (Fig. 4).

On the other hand, out of 1,830 Mann-Kendall tests on the Akşehir precipitation data (1941-2011), 446 (24.37\%) had a negative trend, whereas $235(12.84 \%)$ with a positive trend. Most of the positive trends are concentrated in the upper left corner of the figure, indicating an upward trend (Fig. 5).
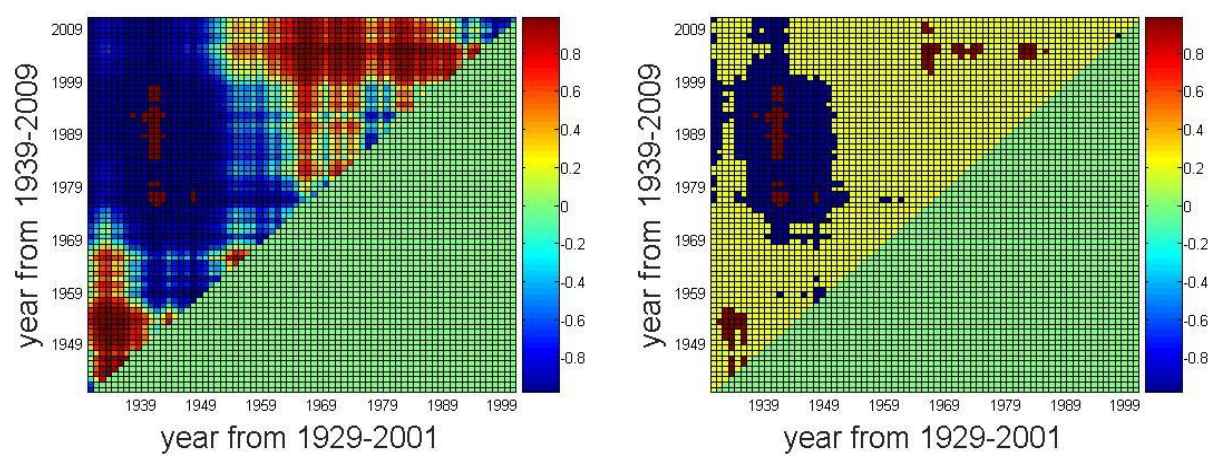

Figure 4. Afyon precipitation trend analysis results $a$-) all confidence intervals $b$-) $95 \%$ confidence interval
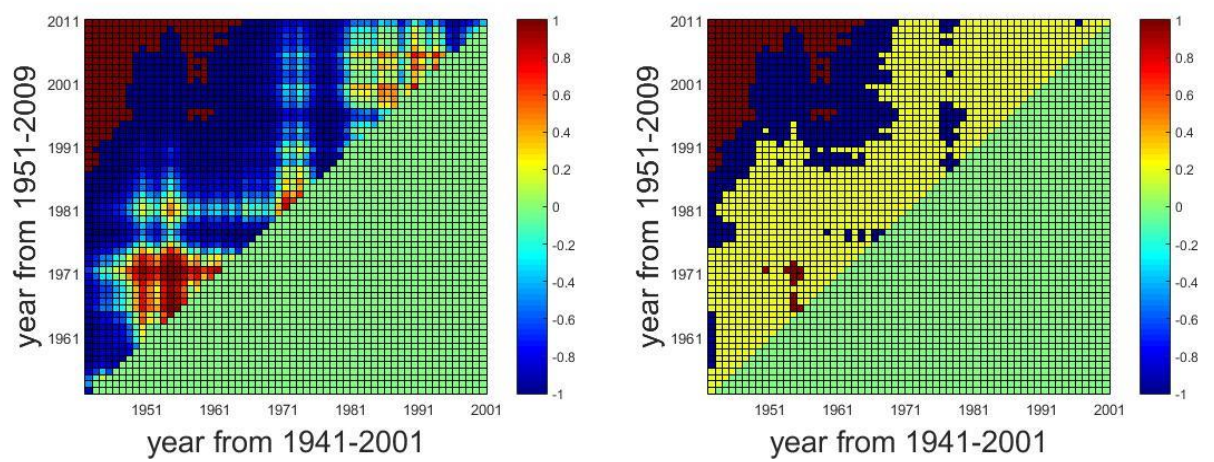

Figure 5. Akşehir precipitation trend analysis results $a$-) all confidence intervals $b$-) $95 \%$ confidence interval 
Mann-Kendall tests conducted 990 times on the Bolvadin precipitation data (19572009), $3(0.30 \%)$ exhibited a negative trend and $2(0.20 \%)$ exhibited a positive trend, with the remaining cases no trend (Fig. 6).

Out of 561 Mann-Kendall tests performed on the Çay precipitation data (1964-2006), $42(7.49 \%)$ showed a negative trend while $1(0.18 \%)$ showed a positive trend. Most of the negative trends are concentrated in the upper left corner of the figure, suggesting that although the number of trends is low, the negative trend has accelerated in recent years (Fig. 7).
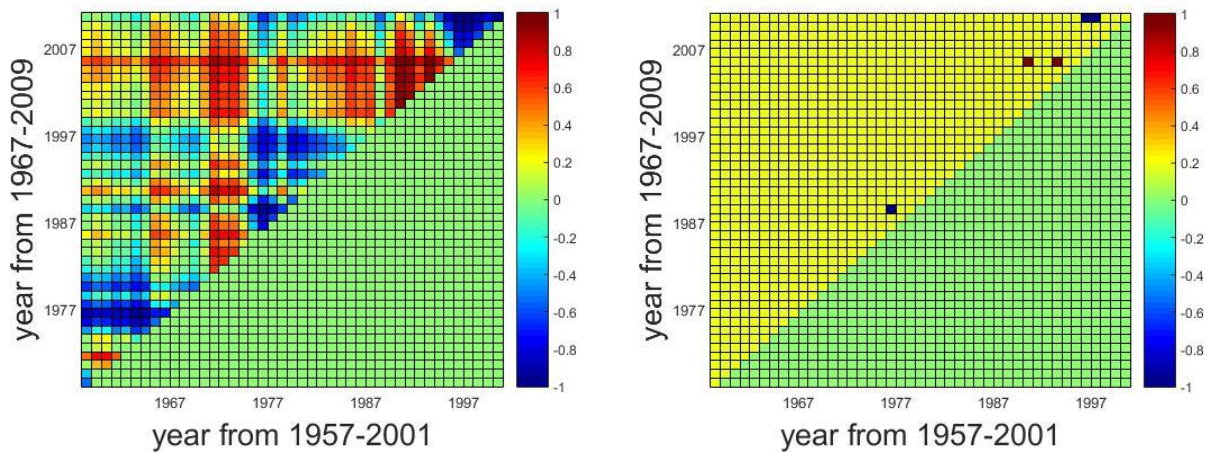

Figure 6. Bolvadin precipitation trend analysis results $a$-) all confidence intervals $b$-) $95 \%$ confidence interval
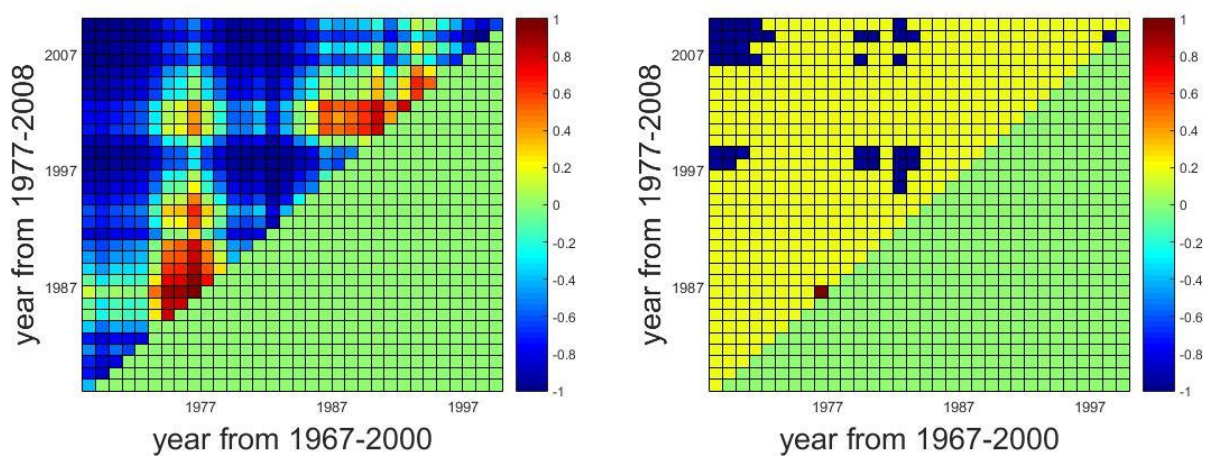

Figure 7. Çay precipitation trend analysis results a-) all confidence intervals $b$-) $95 \%$ confidence interval

\section{Temperature trends}

Mann-Kendall tests are also performed at least for 10 different combinations on the temperature data set at 5 stations. In the classic Mann-Kendall tests, only one analysis is performed at the start and end times of a data set. 2628, 1941, 528, 528 and 666 MannKendall tests are performed for Afyon, Akşehir, Bolvadin, Çay and Emirdă̆, respectively. Trend statistics are given in Table 4.

Similarly, 1,176 Mann-Kendall tests carried out on the Emirdağ precipitation data (1953-2009), $46(3.91 \%)$ had a negative trend, whereas $64(5.44 \%)$ showed a positive trend. The positive trends are concentrated in the lower left corner of the figure, while the negative ones are in the center of the figure, indicating that there has been no trend in recent years (Fig. 8). 
Table 4. Trend statistics for temperature data

\begin{tabular}{c|c|c|c|c|c}
\hline & Iteration & Negative trend & Negative rate & Positive trend & Positive rate \\
\hline Afyon & 2628 & 245 & 9.34 & 94 & 3.58 \\
Akşehir & 1941 & 11 & 0.57 & 79 & 4.07 \\
Bolvadin & 528 & 0 & 0.00 & 153 & 28.98 \\
Cay & 528 & 0 & 0.00 & 32 & 6.06 \\
Emirdağ & 666 & 33 & 4.95 & 46 & 6.91 \\
\hline
\end{tabular}
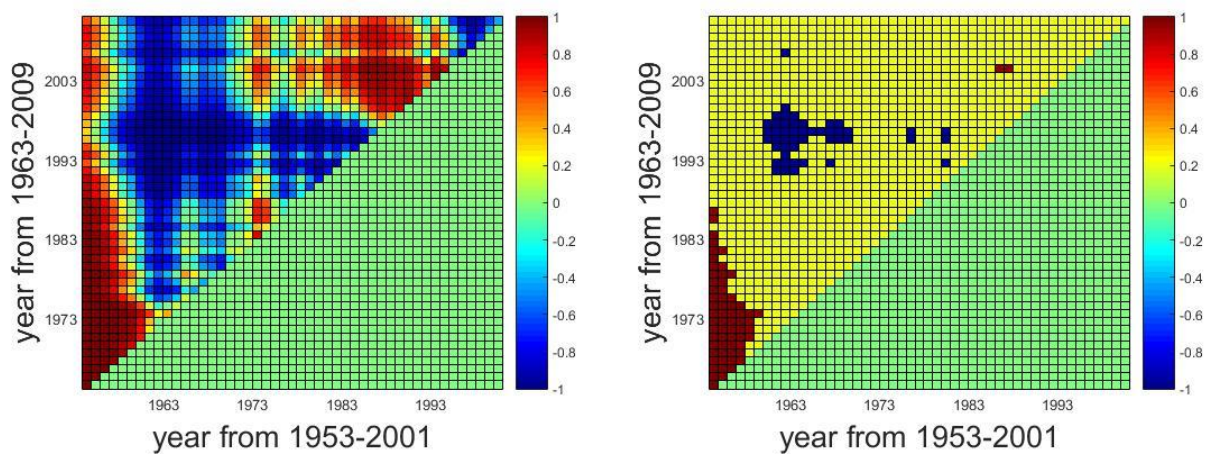

Figure 8. Emirdăg precipitation trend analysis results $a$-) all confidence intervals $b$-) $95 \%$ confidence interval

Trend analyses performed for different periods are visually presented on the checkerboard. Out of 2,628 Mann-Kendall tests on the Afyon temperature data, 245 $(9.34 \%)$ had a negative trend, while 94 (3.58\%) had a positive trend (Fig. 9).
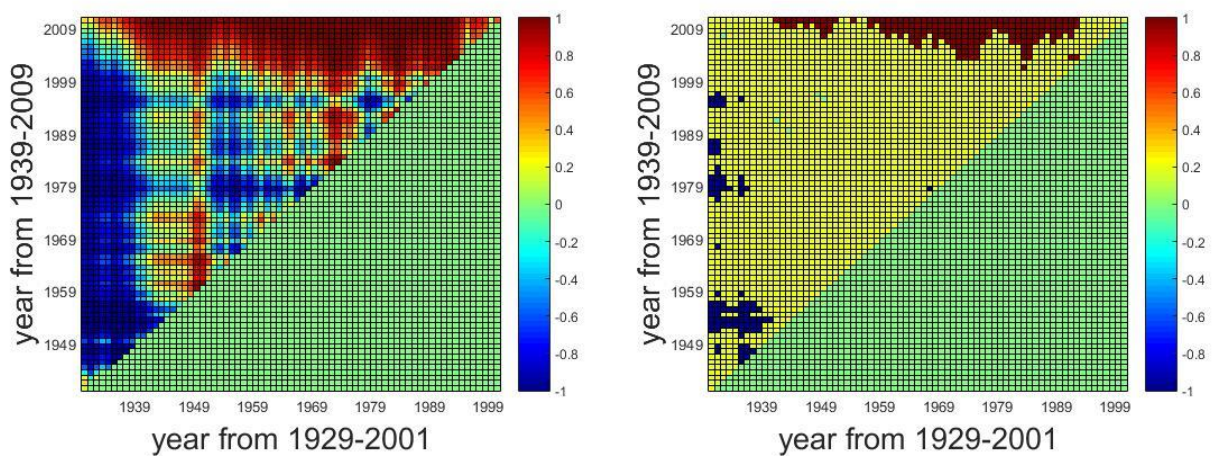

Figure 9. Afyon temperature trend analysis results $a$-) all confidence intervals $b$-) $95 \%$ confidence interval

On the other hand, 1941 Mann-Kendall tests performed on the Akşehir temperature data (1953-2009), yielded $11(0.57 \%)$ negative trends and $79(4.07 \%)$ exhibited a positive trend. The lack of positive trends, especially on the left side of the figure, indicates that the trend in this region is not pronounced (Fig. 10).

Similarly, out of 528 Mann-Kendall tests conducted on the Bolvadin temperature data (1969-2009), $0(0 \%)$ had a negative trend with $153(28.98 \%)$ positive trend. The concentration of positive trends at the top of the figure suggests that trends in this region 
have increased. However, when the classical Mann Kendall test is applied, only one value would be expected to be as 0.05 (the only cell in the upper left corner of the figure, and therefore, no trend would be reported (Fig. 11).

Additionally, out of 666 Mann-Kendall tests carried out on the Çay temperature data (1969-2009), 33 (4.59\%) and 46 (6.91\%) exhibited a negative and positive trend, respectively. The distribution of cells on the figure does not suggest that there is no trend (Fig. 12).
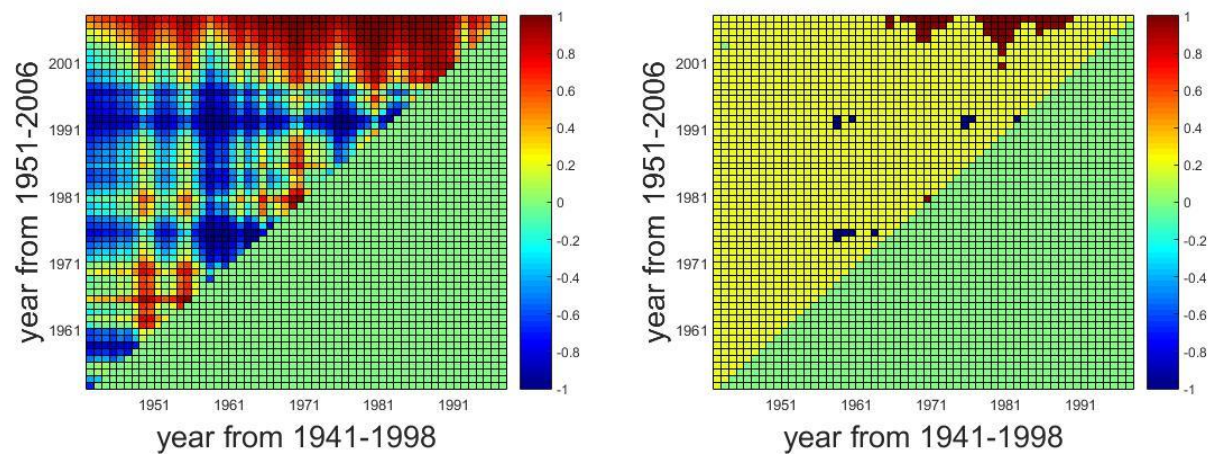

Figure 10. Akşehir temperature trend analysis results $a$-) all confidence intervals $b$-) $95 \%$ confidence interval
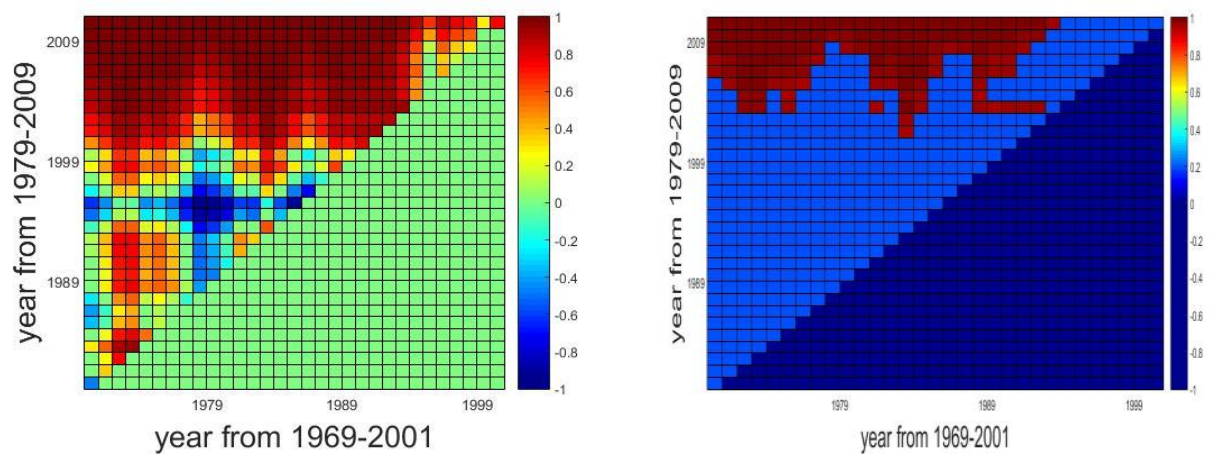

Figure 11. Bolvadin temperature trend analysis results $a$-) all confidence intervals $b$-) $95 \%$ confidence interval
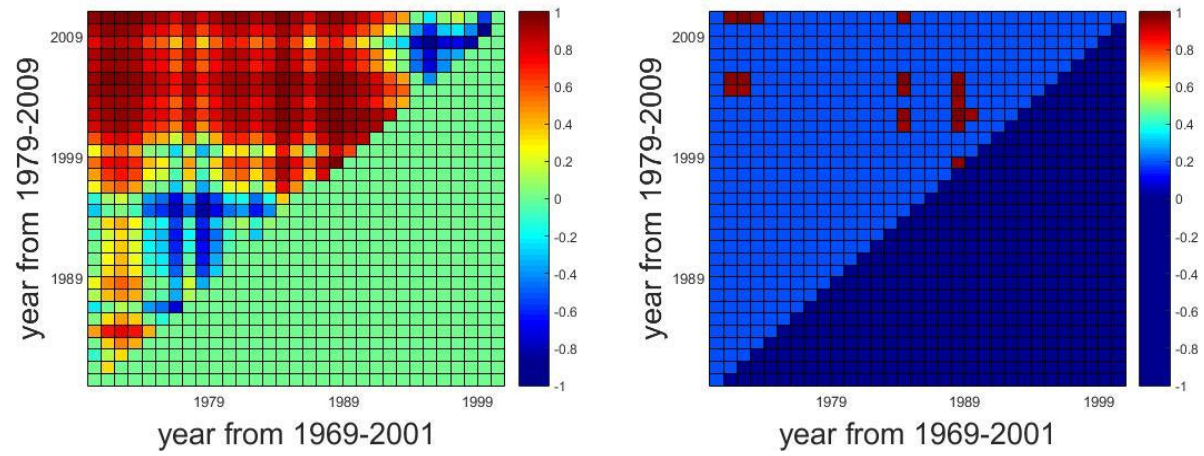

Figure 12. Çay temperature trend analysis results $a$-) all confidence intervals $b$-) $95 \%$ confidence interval 
Finally, out of 666 Mann-Kendall tests applied to the Emirdağ temperature data (1965-2009), 46 (3.91\%) revealed a negative trend with 64 (5.44\%) positive trend. Figure 13 shows that all the negative trends are associated with the 1965-1995 data and that recent data do not indicate the presence of a trend (Fig. 13).
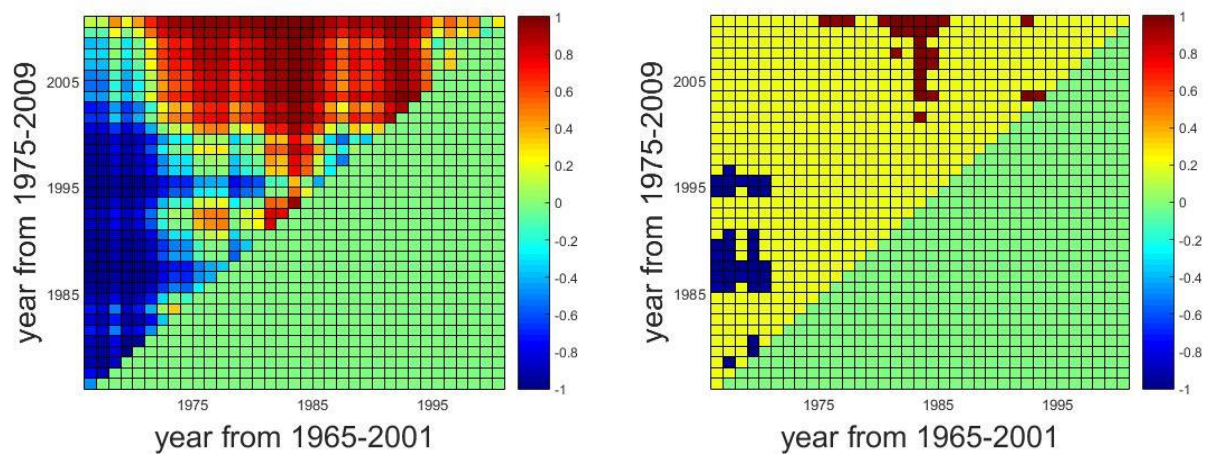

Figure 13. Emirdăg temperature trend analysis results $a$-) all confidence intervals $b$-) $95 \%$ confidence interval

In many studies, the initial and end values of the data are available (Saplioglu et al., 2014; He et al., 2017; Quan et al., 2018). These dates are the dates when records started and records were reached. In this study, it was tried to get answers to questions such as how different the trend would be if the record started to be recorded at a later date than the records started to be recorded, or whether the study would affect the trend values that were made $n$ years ago or $n$ years later. (n-10) (n-9) / 2 studies are possible since a minimum period of 10 years is selected. In this study, all possibilities for all stations are found and shown on checkerboard. For example, the first data from the Emirdag temperature station were taken in 1973, and in 2008 the researcher who was working did not observe the trend formation, but in 2009, another researcher in the researcher determined the positive trend.

\section{Conclusion}

Trend identification is as important as data analysis for the assessment of water resources. The Mann-Kendall test is one of the most commonly used methods for trend analysis. However, changing the start or end time of a period can result in different trend values. In this study, Mann-Kendall tests are performed on all subsets (each having 10 or more year's data). Confidence intervals of $\mathrm{z}$ values are determined and displayed three-dimensionally on a checkerboard.

Data from five precipitation and five temperature stations on Akarçay basin in Turkey, are evaluated and their trends are presented on the checkerboard. Results indicate that the precipitation tends to decrease in Akşehir station and that the temperature significantly increases in Bolvadin station.

This study has eliminated the problem of "time interval selection" for the MannKendall test. For example, Afyon meteorology station precipitation data indicate the presence of a trend between 1929 and 2009 at a confidence interval of 95\%. However, no trend is detected in the data if the start year is 1930 or the end year is 2008. Similarly, although the increasing trend in recent years in the Bolvadin temperature data 
is conspicuous on the checkerboard, the classical Mann-Kendal test fails to detect a trend at a confidence interval of $95 \%$. The analyses in this study are performed for each time interval, and therefore, trend analysis is better analyzed graphically. In addition, using software to analyze the data allowed obtaining individual trend results for all time periods in a very short time. The study is important in terms of showing that different trends can be found in the same station at different periods.

\section{REFERENCES}

[1] Bacanli, U. (2017): Trend analysis of precipitation and drought in the Aegean region, Turkey. - Meteorological Applications 24(2): 239-249.

[2] Baria, S., Rahman, M., Hoqueb, M., Hussain, M. (2016): Analysis of seasonal and annual rainfall trends in the northern region of Bangladesh. - Atmospheric Research 176-177: $148-158$.

[3] Bustins, J., Vide, J., Lorenzo, A. (2008): Iberia winter rainfall trends based upon changes in teleconnection and circulation patterns. - Global and Planetary Change 63: 171-176.

[4] Cannarozzo, M., Noto, L., Viola, F. (2006): Spatial distribution of rainfall trends in Sicily (1921-2000). - Physics and Chemistry of the Earth 31: 1201-1211.

[5] Carvalhoa, J., Assad, E., Oliveiraa, A., Pinto, H. (2014): Annual maximum daily rainfall trends in the Midwest, southeast and southern Brazil in the last 71 years. - Weather and Climate Extremes 5(6): 7-15.

[6] Casaa, A., Nasello, O. (2010): Breakpoints in annual rainfall trends in Córdoba, Argentina. - Atmospheric Research 95: 419-427.

[7] Cui, L., Wang, L., Lai, Z., Tian, Q., Lİu, W., Li, J. (2017): Innovative trend analysis of annual and seasonal air temperature and rainfall in the Yangtze River Basin, China during 1960-2015. - Journal of Atmospheric and Solar Terrestrial Physics 164: 48-59.

[8] Gebert, W., Radloff, M., Considine, E., Kennedy, J. (2007): Use of streamflow data to estimate base flow/ground-water recharge for Wisconsin. - Journal of the American Water Resources Association 43(1): 220-236.

[9] Goenstera, S., Wiehlea, M., Gebauerb, J., Mohamed Alic, A., Stern, R., Buerkert, A. (2015): Daily rainfall data to identify trends in rainfall amount and rainfall-induced agricultural events in the Nuba Mountains of Sudan. - Journal of Arid Environments 122: 16-26.

[10] Guclu, Y. S., Sisman, E., Yelegen, M. (2018): Climate change and frequency-intensityduration (FID) curves for Florya station, Istanbul. - Journal of Flood Risk Management 11(1): 403-418.

[11] He, H. P. Wu, S. J., Ma, M. H., Wen, Z. F., LV, M. Q., Chen, J. L. (2017): Spatial distribution and temporal trend of pan evaporation in the three gorges reservoir area and its surroundings during 1952-2013. - Applied Ecology and Environmental Research 15(3): 1594-1610.

[12] Kamruzzamana, M., Beechama, S., Metcalfe, A. (2016): Estimation of trends in rainfall extremes with mixed effects models. - Atmospheric Research 168: 24-32.

[13] Khan, A., Chatterjee, S., Bisai, D. (2017): Air temperature variability and trend analysis by non-parametric test for Kolkata observatory, West Bengal, India. - Indian Journal of Geo-Marine Sciences 46(5): 966-971.

[14] Karmesha, N. (2012): Trend Detection in Annual Temperature \& Precipitation using the Mann-Kendall Test. A Case Study to Assess Climate Change on Select States in the Northeastern United States. - Master of Environmentail Studies Capstone Project. Dept. of Earth and Environmental Science, University of Pennsylvania.

[15] Kendall, M. (1975): Rank Correlation Methods. - Charles Griffin, London. 
[16] Kim, B., Hossein, H., Choi, G. (2011): Evaluation of temporal-spatial precipitation variability and prediction using seasonal ARIMA model in Mongolia. - KSCE Journal of Civil Engineering 15(5): 917-925.

[17] Kristo, C., Rahardjo, H., Satyanaga, A. (2017): Effect of variations in rainfall intensity on slope stability in Singapore. - International Soil and Water Conservation Research 5(4): 258-264.

[18] Kumar, S., Merwade, V., Kam, J., Thurner, K. (2009): Streamflow trends in Indiana: Effects of long term persistence, precipitation and subsurface drains. - Journal of Hydrology 374: 171-183.

[19] Mann, H. (1945): Non-parametric test against trend. - Econometrika 13: 245-259.

[20] Oliveira, P., Silva, C., Lima, K. (2017): Climatology and trend analysis of extreme precipitation in subregions of Northeast Brazil. - Theoretical and Applied Climatology 130(1-2): 77-90.

[21] Onyutha, C. (2016): Statistical analyses of potential evapotranspiration changes over the period 1930-2012 in the Nile River riparian countries. - Agricultural and Forest Meteorology 226: 80-95.

[22] Onyutha, C., Tabari, H., Taye, M., Nyandwaro, G., Willems, P. (2015): Analyses of rainfall trends in the Nile River Basin. - Journal of Hydro-environment Research 1-16.

[23] Partal, T., Kahya, E. (2006): Trend analysis in Turkish precipitation data. - Hydrological Proceses 20: 2011-2026.

[24] Paul, A., Bhowmik, R., Chowdary, V., Dutta, D., Sreedhar, U., Sankar, H. (2017): Trend analysis of time series rainfall data using robust statistics. - Journal of Water and Climate Change 8(4): 691-700.

[25] Quan, L., He, Y., Zhang, X. (2018): Trend in natural illuminance levels by Mann-Kendall method in Chongqing, China. - Applied Ecology and Environmental Research 16(5): 6655-6665.

[26] Saplığlu, K. (2015): A New methodology for trend analysis: A case study in Burdur and Isparta, Turkey. - Fresenius Environmental Bulletin 24(10a): 3344-3351.

[27] Saplığlu, K., Kilit, M., Yavuz, B. K. (2014): Trend analysis of streams in the western mediterranean basin of Turkey. - Fresenius Environmental Bulletin 23(1a): 313-324.

[28] Saplığlu, K., Küçükerdem, T., Alqaysi, R. (2017): Akdeniz Bölgesi akarsularının su kalitesi sınıflarının ve trendlerinin belirlenmesi. - Dicle Üniversitesi Mühendislik Dergisi 8(1): 33-42.

[29] Seo, L., Kim, T., Kwon, H. (2012): Investigation of trend variations in annual maximum rainfalls in South Korea. - KSCE Journal of Civil Engineering 16(2): 215-221.

[30] Singh, V., Goyal, M. (2016): Analysis and trends of precipitation lapse rate and extreme indices over north Sikkim eastern Himalayas under CMIP5ESM-2M RCPs experiments. - Atmospheric Research 167: 34-60.

[31] Syafrina, A., Zalina, M., Liew, J. (2015): Historical trend of hourly extreme rainfall in Peninsular Malaysia. - Theoretical and Applied Climatology 120: 259-285.

[32] Xu, Z., Li, J., Liu, C. (2007): Long-term trend analysis for major climate variables in the Yellow River basin. - Hydrological Processes 21(14): 1935-1948.

[33] Yue, S., Hashino, M. (2003): Long term trends of annual and monthly precipitation in Japan. Journal of the American - Water Resources Association 39: 587-596.

[34] Zeleňáková, M., Vido, J., Portela, M., Purcz, P., Blištán, P., Hlavatá, H., et al. (2017): Precipitation Trends over Slovakia in the Period 1981-2013. - Water 9(12).

[35] Zhao, J., Xu, J., Li, X., Zhong, Y., Han, D., Qiu, H. (2017): Characteristics analysis of spatial and temporal variation on extreme weather events in Anhui Province for recent 50 years. - Natural Hazards 89(2): 817-842. 